\title{
Women, Gender, and Politics in Morocco
}

\author{
Moha Ennaji \\ International Institute for Languages and Cultures, University of Fès, B.P. 50, Fès 30 000, Morocco; \\ mennaji2002@yahoo.fr; Tel.: +212-673-102-923 \\ Academic Editor: Nancy A. Naples \\ Received: 29 March 2016; Accepted: 10 November 2016; Published: 18 November 2016
}

\begin{abstract}
This article analyzes the intersection of gender, women's activism, and political participation in Morocco in a socio-political approach. The emergence of women's activism is an answer to the gender-based discrimination in the country. Women's non-government organizations (NGOs) struggle for women's rights and participate actively in the feminization and democratization of the public sphere to ensure sustainable development. They create progressive social change through the mobilization and participation of women. The role of women's NGO's (liberal and Islamic alike) in the struggle against gender inequalities is remarkable in regard of their efforts to consolidate democracy and social justice and to challenge traditional thinking and inequitable, oppressive, undemocratic, sexist practices of governance. Despite the different approaches, they act together to achieve women's rights in a variety of places.
\end{abstract}

Keywords: feminism; activism; Islam; politics; Muslim women; non-government organizations; democratization; gender inequality; oppression; women's empowerment

\section{Introduction}

This article analyzes the status of women in contemporary Morocco. Although it is culturally varied, Morocco has many similarities with other Middle Eastern and North African (MENA) countries in relation to women that are significant and profound: a strong religion (Islam), co-habitation of tradition and modernity, and a transitional phase in the processes of democratization and development. The article seeks to demonstrate the importance of women's activism and political participation and their role in the promotion of democracy in this country.

Women's issues have recently become an important political topic that attracts the attention of decision-makers, activists, researchers, and politicians. Both women and men were involved in the birth of modern feminism. Together, they resisted the forces of patriarchy, which deprived them of their civic rights. The men who were involved were mostly highly educated, with legal training and exposure to European thought, and the women belonged to a generation where educated daughters had illiterate mothers [1]. This was accompanied by a wave of enlightenment and awakening in the realms of philosophy and political thought. One of the major Moroccan male pioneers of women's rights is Mohamed Bin Al Hassan Ouazzani, who played a crucial political role in spreading progressive ideas on the emancipation of women. His work was continued by his colleagues, especially Allal Al Fassi. Contemporarily, the most well-known feminist leader in Morocco is Fatema Mernissi.

Across the country, women play a crucial role in socio-economic development despite the fact that there are large inequalities between men and women as far as access to resources is concerned. In the labor market, which is marked by labor and gender division, women have growing responsibilities in ensuring the survival and well-being of the family and in doing their share of farming and of production, small trade, and services.

In this study, I adopt feminist intersectionality theory which understands women's experiences through the intersection of diverse forms of oppression based on gender, race, class, politics, age, 
ethnicity, religion, citizenship, ability, and appearance [2-4]. This theory fits in within my approach in the sense that it underlines the interconnection of various kinds of oppression faced by Moroccan women on a daily basis because of their gender, class, age, ethnicity, appearance, and religion. These regular types of oppression overlap in Moroccan women's lives, leading to complex impacts, as we shall examine in the following section, where I discuss the contributions of NGOs to women's empowerment and to sustainable development [4].

\section{Diversity of Feminisms}

Generally speaking, there are three main views about women's rights in the region. First, Muslim-majority states like Tunisia and Morocco, which have historically chosen the semi-secular path, are viewed as more supportive of women's rights, for instance, through more liberal family codes. They perceive that Islam is not incompatible with women's rights. However, recently Islamist (fundamentalist) groups that seek to oppose the Western model of modernity and to rid off colonial legacy advocate a return to 'purer' forms of the Islamic code of conduct. For this second view, veiling and traditional interpretations of Shari'a (Islamic law) and family codes regulating marriage and divorce are instances of such a comeback. Women and men have lately become more attached to conservative Islamic values and more observant of Islamic behaviors than the previous generation, and view Islam as a way of reclaiming their true identity [5]. A third view, based on a distinctly Islamic perception of feminism, claims that Islam and women's rights are not inherently antagonistic. Moderate Islamic feminists, who hold this view, posit that women's rights are guaranteed within Islam if we adopt a favorable interpretation of religious texts, which promotes women's status while refuting a purely secular attitude to women's emancipation (e.g., [6,7]).

After independence (1956), secularism was viewed as a means to attain gender equality; however, today for many Islamists its links with the Western lifestyles and political systems that separate between religion and state are synonymous with imperialism and secularism, which are associated with secular-authoritarian regimes in the MENA region. In response to this view, which equates feminism with Western imperialism, three major types of feminism in Morocco have emerged, each of which conveys progressive narratives on women's rights: Islamic, reformist, and secularist [8-10]. The first two types view Islam as compatible with women's rights, yet they differ in interpretation in the sense that the Islamic feminists interpret women's rights within the teachings of Islam while the reformists adhere to modern views of feminism while not rejecting Islam; by contrast, the secularist trend sees religion and women's rights as predominantly paradoxical.

The Islamic revivalist movements, which have been flourishing throughout the MENA area since the mid-1980s, have ignited debate over the role of women in contemporary society [11]. The social agendas of these revivalists propagate Islamic practices, although there has always been a lack of consensus on the content of those practices.

To understand the nature and impact of Moroccan women's activism, it is important to relate it to the rise of Islamism in the region. While not rejecting the Qur'an, reformist feminists adhere to the view that Islam as a culture is compatible with feminism. They, in a way, compromise the views of both the Islamic and the secular feminists. The Moroccan writers Fatema Mernissi and Leila Abouzeid are good cases in point, for they both stress that Islam itself is not the root cause of the gender problems, but rather the anti-woman interpretations of the faith, as well as fictitious accounts of Prophet Muhammad's sayings and ideas, that have developed the misogyny which their work exposes and fights. Reformist activists participate in interreligious/interfaith dialogues and networks by reaching out to Islamist organizations and at times using their discourse to increase their constituency.

In contrast, secular feminists often advocate a non-Islamic interpretation of traditions and laws related to women's position, while Islamic feminists support gender equity, but equally advocate Islamic interpretations of laws and customs regarding women. Secular feminism in Morocco adopts Western feminist views while maintaining national and cultural identity. Its proponents think that, although feminism can be easily rejected in the name of religious and ideological conservatism, it cannot be easily rejected in the name of cultural authenticity. 
Secular organizations struggle for a liberal societal project, while Islamic women's associations work within the framework of Islam and aim for the Islamization of the country. Secularists adhere to the view that Islam is incompatible with feminism. Their doctrine is often rooted in leftist political movements, which do not see any compatibility between the two concepts of Islam and feminism. For these secular feminists, women's liberation requires a thorough de-Islamization of all aspects of life. In fact, a number of left-wing scholars attribute the problems of contemporary Arab women to Islam [12].

Thus, secular feminists see women's rights as attainable only by means of the separation of state and Islam, while the Islamic and reformist feminists view women's rights as consistent with Islam and only attainable through the positive interpretations of religious texts like the Qur'an (the holy book of Muslims) and the Hadith (The Prophet Muhammad's sayings).

\section{Women's NGOs and Feminist Praxis in Morocco}

Moroccan feminists (secular, reformist, and Islamic alike) endeavor to promote women's empowerment through education, knowledge, and legal rights; they raise women's awareness about the family law and the labor code through their NGOs and community-based groups. Women's activism has considerably contributed to democracy in the region, particularly in North African countries like Tunisia, Morocco, and Algeria, due to its greater social involvement in social and political affairs and due to the proliferation of women's associations and women's access to the media. Women's activism is essential to modernization and democratization, for it has significantly contributed to the advance of civil society and democratic culture. One cannot imagine the success of democracy in this region of the world without the full emancipation of women.

The emergence of women's NGOs is an answer to the crisis of the nation-state model form of governance. Such grassroots associations are treated as a way to ensure democracy and sustainable development. They create social dynamism through the mobilization and participation of the oppressed. They also decentralize governance in a more globalized world. Their modes of action raise new challenges for government development policies and open up new avenues of thinking about the issues of sustainability.

In order to appreciate the significance of women's activism in Morocco, it is essential to underscore the role of feminist NGOs taking into account women's own interpretations, needs, and views of gender equality and development in order to respond to local realities, needs, and demands. Women's NGOs play a major role in the struggle against gender inequalities and highlight their agency to consolidate democracy and social justice and to challenge traditional thinking and oppressive, sexist practices of governance $[8,13]$.

The number of women's NGOs in Morocco has exploded during the last two decades, representing both the channeling of energies and passions into directly addressing and trying to solve single issues about which women care profoundly, as well as the recognition of the limitations of government programs in addressing social problems. An attempt to counterbalance neo-liberal policies may have led to the expansion of NGOs emphasizing women's rights, humanitarian issues, developmental aid, and sustainable development.

Some women's NGOs attempt to solve perceived problems directly, such as by capacity building, or by establishing income-generating activities, orphanages, shelters for battered women, or schools. Other attempts have been made to pressure - through lobbying, demonstrations, advocacy campaigns, and other means-the government and the private sector into undertaking solutions and reforms. Women's NGO's are also active in politics, peace, and legal and human rights, among innumerable others.

In Morocco, many women's NGOs have been charged with a lack of professionalism and a lack of accountability, for their staff is not always well trained in accounting, finance, fund-raising, and computing skills. Despite problems related to a lack of training, information, and expertise in collective management and initiatives, as well as weak communications (both internally and 
externally) and a heavy reliance on international donor agencies for financing, Moroccan NGOs strive hard to empower women through mobilizing different actors in civil society, decentralization, and the development of their members' skills. Women's NGOs are usually characterized by pragmatism and clear objectives, namely improving women's socioeconomic conditions, integrating them in development and ensuring their participation in public life. They adopt strategies and actions that enable them to achieve sustainability through the empowerment of women with the support of the state [13].

State feminism, which may be defined as the government's official policy for the emancipation of women, started to develop in Morocco since independences in 1956. It is considered a historical strategy that has been adopted in different parts of North Africa to improve women's conditions and to contribute to their well-being [14]. Thus, the provision of education, health, and work to women helped to brighten up the image of the state. In Morocco, state feminism started during Kind Mohammed V's regime (1956-1960), and continued to develop under King Hassan's reign and currently under King Mohammed VI's rule, which promised equality of men and women and a better life quality. However, in the long run, its main beneficiaries were people from the aristocracy and the upper class $[15,16]$.

However, in the 1980s, with the application of economic reforms (the structural re-adjustment plan), the economic and social retreat of the state began, which weakened the prospects for a better future for the working class and the middle-class women. Thus, although state feminism succeeded in giving women access to education, health, and employment, it did not really challenge the negative social and cultural attitudes toward women who are still regarded as dependent on men.

At the socio-political level, after the political reforms of the 1990s (re-amendment of the constitution and law on elections), which led to more democratization, a large number of women's associations emerged; this had a great national and regional impact on policy and legal matters such as the family code and the reform of the citizenship law. As a case in point, we cite the following major associations: l'Union Féminine Marocaine and l'Organisation Démocratique des Femmes du Maroc. Both defend women's rights and the values and principles of equal citizenship. Their strategy revolves around promoting gender equality through progressive public policies, laws, and practices. Their mission is the protection and promotion of women's strategic interests as universally recognized.

By communicating across the diverse channels and by forming advocacy networks, women's NGOs have been able to impose changes to criminal laws, including article 475 of the penal code that allowed a rapist to escape punishment if he married his victim. This law has recently been supplanted by a new one which stipulates that "a rapist goes to jail and cannot marry his victim" [17]. However, despite the dynamism of their organizations, women are still disfavored at the judiciary level in legal matters (e.g., in polygamy and inheritance). The conservative forces regard women's role to be limited to home, reproduction, and child rearing.

Women's NGOs promote women's emancipation, participation, and social mobilization. They encourage women's empowerment and participation in decision-making and in public affairs. They have enabled women to critically assess their own situation and shape a transformation of society (cf. [18]).

Women's NGOs engage in diverse activities; as a result, they have accumulated a great deal of experience in mobilizing women and in local development. Unlike in many Arab countries, Moroccan women's NGOs are allowed by the government to receive financial aid from foreign organizations and donors. Yet the challenge facing these NGOs is to elaborate autonomous strategies and to establish themselves as independent forces in their partnership with the state and with political parties. Many associations manage this by keeping a distance from political parties, which still have little credibility with the people.

NGOs continue to keep their autonomy from the state and from political conflicts, as it is easier to agree on the need to promote girls' education or protect women's rights than to congregate on issues that involve collaborating with the government or boycotting elections, for example. In order to survive, some NGOs resort to financial support from the West, as mentioned above. Nevertheless, 
it has by now become clear to these NGO leaders that in order to foster the democratization process in the country, they must join forces with the political parties that will help aggregate and represent women's societal interests in Parliament and government. The parties are the political actors who could deliver social and political change in a nation-wide policy. Now, civil society activists work for a healthy relationship between NGOs and political parties through cooperation, but at a distance. They are also involved in projects that promote the emancipation of women by the development of coalitions between NGOs, parties, and state organizations. Working alone is simply unproductive. Without collaboration with the political actors, NGOs cannot convince the people of the possibility of realizing reforms and achieving a democratic system in Morocco.

Over the last decade, Moroccan women's NGOs have intensified their efforts to improve women's living conditions. Thus, many associations fight gender-based violence and assist battered women by giving them shelter and legal advice. A network of several associations has been created, organizing numerous activities and campaigns to raise awareness about gender equality, the promotion of women's rights, tolerance, and citizenship. They have been successful in using the media, especially television, in order to make their voices heard and to contribute to the debate on equality between the sexes. In 1998, the first national campaign against violence against women was organized. This campaign mobilized many government departments and ministries, as well as civil society. As an outcome of this campaign, the Ministry of Family has adopted a national strategy to combat violence against women, and recently the government has initiated a phone line for women victims of violence who want to seek help or make a complaint about domestic violence.

Feminist activists have realized important accomplishments, namely the elimination of the authorization of the husband for traveling abroad (2004), or for practicing a trade activity (1995), the revision of the work code and of the penal code (2003), and the reform of the citizenship law which now allows a Moroccan woman to transmit her citizenship to her children. Yet the most remarkable achievement is the reform of the family law (in October 2004). The latter came after more than 20 years of struggle by feminists.

The principal changes brought out by this code are, briefly: (1) the family is considered the responsibility of both the husband and the wife, rather than having the sole power resting on the husband; (2) couples must appear before a judge before contracting marriage and when filing for divorce; (3) both boys and girls can marry at the age of 18-in the previous code (1958), girls could get married at the age of 16; (4) the elimination of tutorship for women-women now can marry without the authorization or agreement of their father; (5) divorce is regulated by new laws, which are enforced by the family court; (6) in case of divorce, the property and financial resources accumulated by the household during marriage are shared by the two spouses-in the previous family code, the wife had no right to claim a portion of the property and money of the husband; (7) women now have the right of custody over their children even in case they remarry-in the old law, the mother lost custody over her children the moment she remarried another man.

However, the new family code has its own limitations and imperfections despite its advantages and its positive impact on women and families. For example, although polygamy is significantly controlled, it is legally accepted, and inequality concerning inheritance is still maintained, whereby a woman inherits half the part of a man. When there are no males among the inheritors, the females inherit only part of the legacy and the rest goes to the family of the deceased male.

Furthermore, cultural hurdles and patriarchal traditions, illiteracy, and lack of information prevent women from invoking their rights or reporting crimes against them, such as rape, child abuse, sexual exploitation and domestic violence. Concerning such cases, lawyers do not often make legal arguments based on international human rights treaties.

Moreover, illiteracy is more widespread among women (60\%) than among men (40\%). Although women play a growing role in development, they still suffer from many social injustices, such as unequal pay and poverty [19]. They have had little access to top jobs or decision-making positions, which is mainly due to negative attitudes and taboos against women $[6,12]$. 
As a consequence of the advocacy of women's groups, the Moroccan government has recently launched a campaign to fight against poverty and illiteracy among rural women, which had a great impact on poor women's welfare and people's attitudes toward women in general and toward their political participation.

\section{Political Participation}

Under the pressure of women's associations and other democratic forces, the government ratified the Convention on the Elimination of All Forms of Discrimination against Women (CEDAW) in 2008 without any reservation and amended the constitution in 2011, following the protests of the Arab Spring. In recent years, a number of measures have been taken to improve the status of women in Morocco and to ensure their political participation. Women's rights groups and human rights activists took a unique approach to tackling gender parity on the political stage first by addressing inequality within the household through the reform of family code in 2004 and second by presenting women's rights as a political demand.

As a result, the situation of women has improved over the last two decades at the social and legal levels. The new constitution guarantees women's rights and political participation, which are badly needed to guarantee their empowerment and contribution to society's democratization.

The constitutional reform increased the number of seats reserved for women from 30 out of 325 in 2007 to 60 out of the 395 seats $(15 \%)$ in 2011. Though still well below the $30 \%$ quota claimed by women's movements, it is an improvement from the initial quotas implemented in 2007. Electoral laws have also undergone significant changes to increase the political participation of women, starting with a reform of the ballot system and electoral code in 2002, through the introduction of a proportional list system, followed by the institution of positive discrimination in the form of a gender quota. September 2007 legislature marked the election of 34 women to Parliament: $10.77 \%$ in contrast to $0.6 \%$ in the 2002 elections [20]. In local councils, the participation of women exploded, as the rate of participation multiplied by 22 , increasing from $0.56 \%$ in 2002 to $12 \%$ in 2009 , taking the number of elected women to local councils from less than a hundred to more than 3465 [19]. Today, there are 81 women in Parliament (2016) representing 21\%-nearing the world average. They are present in decision-making positions although in insufficient numbers (five in the government).

On the other hand, Article 19 of the new constitution enhances equality of men and women before the law and underlines the crucial importance of women's sharing of political power and policy-making. Like the family code, the new constitution has been cited as an example of Morocco's progress toward becoming a more democratic society. To promote women's political participation, the state implements Article 19 of the new constitution, as it is fervently demanded by the feminist movement in Morocco in order to foster women's political participation and access to power.

Women's activism constantly reminds political leaders that the national and the international contexts, where legal standards concerning women are applied, can no longer be ignored [21]. Nevertheless the choice between modernity and tradition remains a considerable challenge. In Morocco, which has opted for democratization, this choice cannot ignore either Islam or the socio-economic environment. Another challenge concerns the choice of a model for economic and social development and the gradual integration of women into political life.

Thus, the feminist movement in Morocco has played a major role in the advancement of women's political participation and gender equality. All the reforms that took place would not have been possible without the feminist movement's long struggle and strong advocacy based on real expertise and linked to the grassroots reality and experiences of women.

\section{Conclusions}

This article has underlined the importance of women's representation and political participation, despite many challenges posed by the male-dominated political arena, illiteracy, and the fundamentalist threat. It has emphasized their fight for emancipation and for civil rights, as well as the hard work that 
remains to be done to ensure their access to wealth and to decision-making positions. The struggle that preceded the acquisition of these rights must be remembered, as they were not granted to women on a silver plate, but were earned by feminist struggle and activism. One of the major challenges faced in contemporary feminist praxis is the tension between modernity and tradition. In a country like Morocco, which has opted for multilingualism, liberal economy, and political pluralism in a constitutional monarchy, the alternative cannot be insensitive to Islam nor to the international image (at the Islamic, Arab, African, and global levels) in policy making. The internal context is also important, as it is challenged by the struggle for economic and social development and the place of women in this dynamism.

The new constitution came after seven years of the enactment of the new family law in 2004, which was also hailed as a great step forward for women's rights domestically and as a model for the broader Muslim world [22]. The family code introduced a range of measures that enhance women's equality in marriage, divorce, and other aspects of family life: women are treated as equal to men before the law; divorce is no longer in the hands of the husband; polygamy is drastically restricted; and the woman is free to marry a man of her choice. The family code is remarkable for the additional reason that it has sparked Moroccan society to engage in a public dialogue regarding gender equality in the family. It constitutes a fundamental reform, which has transformed women's status and their image in Moroccan society and confirms the fact that women's rights are part and parcel of democracy and social justice.

Hence, women's organizations and civil society in general have played—and still play-a major role in sensitizing women, families, and social actors to the importance of integrating women in economic, social, political, and cultural development. Likewise, education and training are important for women to enable them to meet the new challenges, and to help them safeguard their rights and interests.

Despite the reforms of the family law and of the constitution in Morocco, which are considered advanced and progressive in the field of women's rights, compared with other countries in the region, women need to be more integrated socially, politically, and economically in order to consolidate the democratization path of the country.

Conflicts of Interest: The author declares no conflict of interest.

\section{References}

1. Sadiqi, Fatima. "The Central Role of the Family Law in the Moroccan Feminist Movement." The British Journal of Middle Eastern Studies 35 (2008): 325-37. [CrossRef]

2. Collins, Patricia Hill. Black Feminist Thought: Knowledge, Consciousness, and the Politics of Empowerment. New York: Routledge, 2000.

3. Crenshaw, Kimberle. "Demarginalizing the intersection of race and sex: A black feminist critique of antidiscrimination doctrine, feminist theory and antiracist politics." University of Chicago Legal Forum 1 (1989): $139-67$.

4. Mullings, Leith. On Our Own Terms: Race, Class and Gender in the Lives of African American Women. New York: Routledge, 1997.

5. Hilsdon, Anne-Marie, and Santi Rozario. "Special Issue on Islam, Gender and Human Rights." Women's Studies International Forum 29 (2006): 331-38. [CrossRef]

6. Mernissi, Fatema. Sultanes oubliées. Femmes Chefs d'état en Islam. Paris: Albin Michel, 1990.

7. Mir-Hosseini, Ziba. “Beyond 'Islam' vs. 'Feminism'." Institute of Development Studies Bulletin 42 (2011): 67-77. [CrossRef]

8. Ennaji, Moha. Minorities, Women and the State in North Africa. Trenton: Red sea Press, 2016.

9. Moghadam, Valentine M. "Islamic Feminism and Its Discontents: Toward a Resolution of the Debate." Signs 27 (2002): 1135-71. [CrossRef]

10. Mir-Hosseini, Ziba. "Muslim Women's Quest for Equality: Between Islamic Law and Feminism." Critical Inquiry 32 (2006): 629-45. [CrossRef] 
11. Badran, Margot. Feminism in Islam: Secular and Religious Convergences. London: Oneworld Publications, 2013.

12. Mogaddam, Valentine. Modernizing Women: Gender and Social Change in the Middle East, 3rd ed. Boulder: Lynne Rienner Publishers, Inc., 2012.

13. Ennaji, Moha. "Women's NGOs and Social Change in Morocco." In Women in the Middle East and North Africa. Edited by Fatima Sadiqi and Moha Ennaji. London: Routledge, 2010, pp. 79-88.

14. Hatem, Mervat. "Economic and Political Liberation in Egypt and the Demise of State Feminism." International Journal of Middle East Studies 24 (1992): 231-51. [CrossRef]

15. Ennaji, Moha. "Steps to the Integration of Moroccan Women in Development." British Journal of Middle Eastern Studies 35 (2008): 339-48. [CrossRef]

16. Zuhur, Sherifa. "Claiming "Space for Minorities in Egypt after the Arab Spring." In Multiculturalism and Democracy in North Africa. Edited by Moha Ennaji. London: Routledge, 2014, pp. 246-74.

17. The Guardian. "How NGOs helped change Moroccan law on rapists marrying their victims." Available online: http:/ / www.theguardian.com/global-development/poverty-matters/2014/feb/07/ngo-changemorocco-rape-law (accessed on 19 December 2014).

18. Sadiqi, Fatima, and Moha Ennaji. “The Feminization of Public Space: Women's Activism, the Family Law, and Social Change in Morocco." Journal of Middle East Women's Studies 2 (2006): 86-114. [CrossRef]

19. Ennaji, Moha. "Women and Political Participation in Morocco and North African States." In Gender and Political Power. Edited by Mino Vianello and Mary Hawkswàrth. London: Palgrave, 2015, pp. 35-52.

20. Tahri, Rachida. "Women's Political Participation: The Case of Morocco." Paper presented at the International Institute for Democracy and Electoral Assistance Conference on the Implementation of Quotas: African Experiences, Pretoria, South Africa, 11-13 November 2003.

21. Naples, Nancy A. "The Challenges and Possibilities of Transnational Feminist Praxis." In Women's Activism and Globalization: Linking Local Struggles and Transnational Politics. Edited by Nancy A. Naples and Manisha Desai. New York: Routledge, 2002, pp. 267-81.

22. Zoglin, Katie. “Morocco's Family Code: Improving Equality for Women.” Human Rights Quarterly 31 (2009): 964-84. [CrossRef]

(C) 2016 by the author; licensee MDPI, Basel, Switzerland. This article is an open access article distributed under the terms and conditions of the Creative Commons Attribution (CC-BY) license (http://creativecommons.org/licenses/by/4.0/). 